Article

\title{
Estimation of Black Carbon Emissions from Dry Dipterocarp Forest Fires in Thailand
}

\author{
Ubonwan Chaiyo $^{1,2}$ and Savitri Garivait ${ }^{1,2, *}$
}

1 The Joint Graduate School of Energy and Environment, King Mongkut's University of Technology Thonburi, Bangkok 10140, Thailand; E-Mail: uchaiyo@hotmail.com

2 Center of Excellence on Energy Technology and Environment, S\&T Postgraduate Education and Research Development Office (PERDO), Commission on Higher Education (CHE), Ministry of Education, Bangkok 10140, Thailand

* Author to whom correspondence should be addressed; E-Mail: savitri_g@jgsee.kmutt.ac.th; Tel.: +662-872-9014-5; Fax: +662-872-9805.

External Editor: Alex B. Guenther

Received: 31 July 2014; in revised form: 10 October 2014 / Accepted: 23 October 2014 /

Published: 5 December 2014

\begin{abstract}
This study focused on the estimation of black carbon emissions from dry dipterocarp forest fires in Thailand. Field experiments were set up at the natural forest, Mae Nam Phachi wildlife sanctuary, Ratchaburi Province, Thailand. The dead leaves were the main component consumed of the surface biomass with coverage higher than $90 \%$ in volume and mass. The dead leaves load was $342 \pm 190 \mathrm{~g} \cdot \mathrm{m}^{-2}$ and followed by a little mass load of twig, $100 \mathrm{~g} \cdot \mathrm{m}^{-2}$. The chemical analysis of the dead leaves showed that the carbon content in the experimental biomass fuel was $45.81 \pm 0.04 \%$. From the field experiments, it was found that $88.38 \pm 2.02 \%$ of the carbon input was converted to carbon released to the atmosphere, while less than $10 \%$ were left in the form of residues, and returned to soil. The quantity of dead leaves consumed to produce each gram of carbon released was $2.40 \pm 0.02 \mathrm{~g}_{\text {dry biomass burned. }}$. From the study, the emissions factor of carbon dioxide, carbon monoxide, particulate matter $\left(\mathrm{PM}_{2.5}\right)$ and black carbon amounted 1329, 90, 26.19 and $2.83 \mathrm{~g} \cdot \mathrm{kg}^{-1}$ dry biomass burned, respectively. In Thailand, the amount of black carbon emissions from dry dipterocarp forest fires amounted 17.43 tonnes $\cdot \mathrm{y}^{-1}$.
\end{abstract}

Keywords: Carbon mass balance; carbon released; emissions; tropical deciduous forest 


\section{Introduction}

Forest fires in dry dipterocarp forest (DDF) occur in Thailand during the dry season, from December to April, when trees shed their leaves, and consequently, the leaf litter can accumulate quickly, and then serve as perfect fuel for burnings to be set by local communities. Fires of tropical deciduous forests, including dry dipterocarp forest and mixed deciduous forest in Thailand are generally man-made. The reasons frequently recorded by forest fire control stations are (1) to facilitate the gathering of non-timber forest product, (2) to ease the access to forest for hunting, and (3) to help land clearing for crop cultivation [1]. The type of fires occurred in DDF is characterized as surface fire, since the fuel is composed of biomass present on the ground surface of the forest, including leaf litter, twig, grass, undergrowth, shrub, climber, and seedling. The leaf litter constitutes the major component of biomass fuel. Studies on fuel consumption indicated that about $95 \%$ of biomass fuels in DDF are consumed by surface fires [2].

Regarding impacts of fires on the ecosystem, it was shown that the frequency of fire can drastically modify the structure and composition of aboveground biomass and affect the carbon cycle. Actually, the more frequent is the burning the lower is the growth rate. It was observed that in the annually burned area, the increase of tree diameter and basal area was lower than that of biennially, which was lower than that of triennially burned, with only $0.237 \mathrm{~cm} \cdot \mathrm{y}^{-1}$ and $0.0007 \mathrm{~m} \cdot \mathrm{y}^{-1}$, respectively. Concerning the survival to fire which depends on the base diameter, it was found that the seedlings with base diameter less than $1 \mathrm{~cm}$ were completely dead after the fire passage [3]. It was revealed that fires directly affect biomass fuel characteristics, as well as underneath soil properties and nutrients dynamics [4]. Indeed, the heat from fires distresses insects on the ground or under the bark wood, and activates the natural regeneration and undergrowth development [3]. Although their adverse effects, it should be noted that fires play an important role in tropical deciduous forest management, because they enable to maintain its plant structure and ecosystem.

On the other hand, emissions from forest fires strongly affect air quality. They include air pollutants and climate forcers such as carbon monoxide $(\mathrm{CO})$, methane $\left(\mathrm{CH}_{4}\right)$, nitrous oxide $\left(\mathrm{N}_{2} \mathrm{O}\right)$, fine particulate matter $\left(\mathrm{PM}_{10}\right.$ and $\left.\mathrm{PM}_{2.5}\right)$, carbonaceous aerosols composed of black carbon $(\mathrm{BC})$ and organic carbon (OC), etc. While these compounds adversely impact the local air quality and long-term climate change, documentations on qualitative and quantitative characteristics of the emissions from dry dipterocarp forest fires in Thailand are still very scarce or inexistent.

In this study, we investigated the emission factor of black carbon from dry dipterocarp forest fires, by burning the leaf litter, which constitutes the major biomass fuel type. The estimation of the carbon dioxide, carbon monoxide, aerosols and carbon content in the biomass fuel and burned residues are presented. The amount of carbon released to the atmosphere and emission factor estimation of black carbon based on the carbon mass balance method of the combustion reaction was then presented and discussed.

\section{Materials and Methods}

\subsection{Study Site Description}

Mae Nam Phachi wildlife sanctuary is located in Ratchaburi province, about $215 \mathrm{~km}$ far from Bangkok, in the western region of Thailand. It is lied between $13^{\circ} 8^{\prime} \mathrm{N}$ to $13^{\circ} 27^{\prime} \mathrm{N}$ latitude and $99^{\circ} 10^{\prime} \mathrm{E}$ 
to $99^{\circ} 25^{\prime}$ E longitude, on a high mountain covering the Suan Pueng district, Khing Amphoe Ban Kha and Park Tho district, close to the border of Thailand and Myanmar, and the altitude for this area ranges from 200 to $1400 \mathrm{~m}$ above the sea level. This wildlife sanctuary has a total area of $489 \mathrm{~km}^{2}$, and the forest types included therein are composed of dry evergreen forest, dry dipterocarp forest, mixed deciduous forest (Figure 1) and pure stand bamboo forest.

In DDF, the research study of Chaiyo et al. [5] reported that the dominant species are Shorea obtusa, S. siamensis, Lannea coromandelica and Dipterocarpus obtusifolius. The tree density

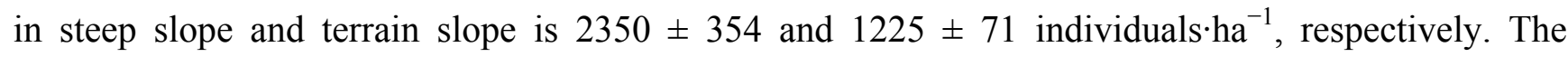
aboveground biomass in steep slope and terrain slope is 91.96 and 30.95 tonnes $\cdot \mathrm{ha}^{-1}$, respectively. The surface biomass is mainly composed of leaf litter, i.e., with coverage higher than $90 \%$ in volume and mass, that can be consumed to release the pollutants into the atmosphere.

Figure 1. Location of Mae Nam Phachi wildlife sanctuary, Ratchaburi Province, Thailand.

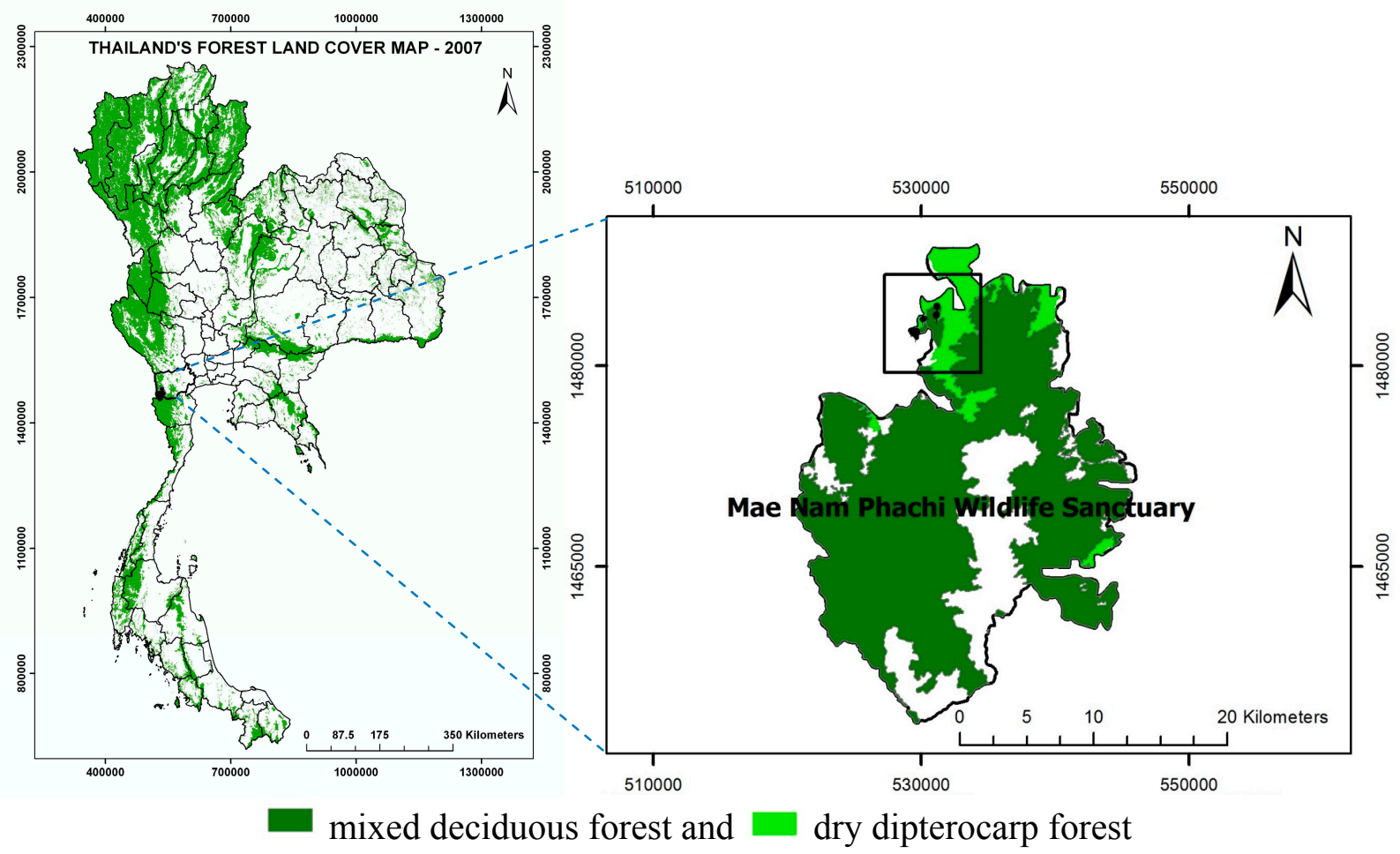

In Ratchaburi Province, the average total rainfall and mean temperature during 2005 to 2009, were 959 to $1285 \mathrm{~mm}$ and $28{ }^{\circ} \mathrm{C}$, respectively, as reported by the Ratchaburi meteorological station. The peak of temperature during dry seasons, especially in April, lied between 30.3 to $31.3^{\circ} \mathrm{C}$. On the other hand, December was the coolest month with temperature ranges from 24.5 to $26.9{ }^{\circ} \mathrm{C}$. January corresponded to the driest month with a total rainfall lesser than $6.5 \mathrm{~mm}$ rainfall, while October constituted the wettest month with 117.6 to $441.5 \mathrm{~mm}$ of rainfall (Figure 2).

The experimental plots were set during dry season, i.e., in February to March. Three experimental plots of 40-m $\times$ 40-m plots were set in DDF. DDF1 and DDF2 were located in steep slope (i.e., slope ranging from 20 to $40 \%$ ) and DDF3 in terrain slope, respectively. The prescribed fire was set in DDF1, and the overall burning occurred in steep slope. The surface biomass fuel was sampled from the three plots. 
Figure 2. Average annual temperature and rainfall profiles in Ratchaburi Province based on records from meteorological station during 2005 to 2009.

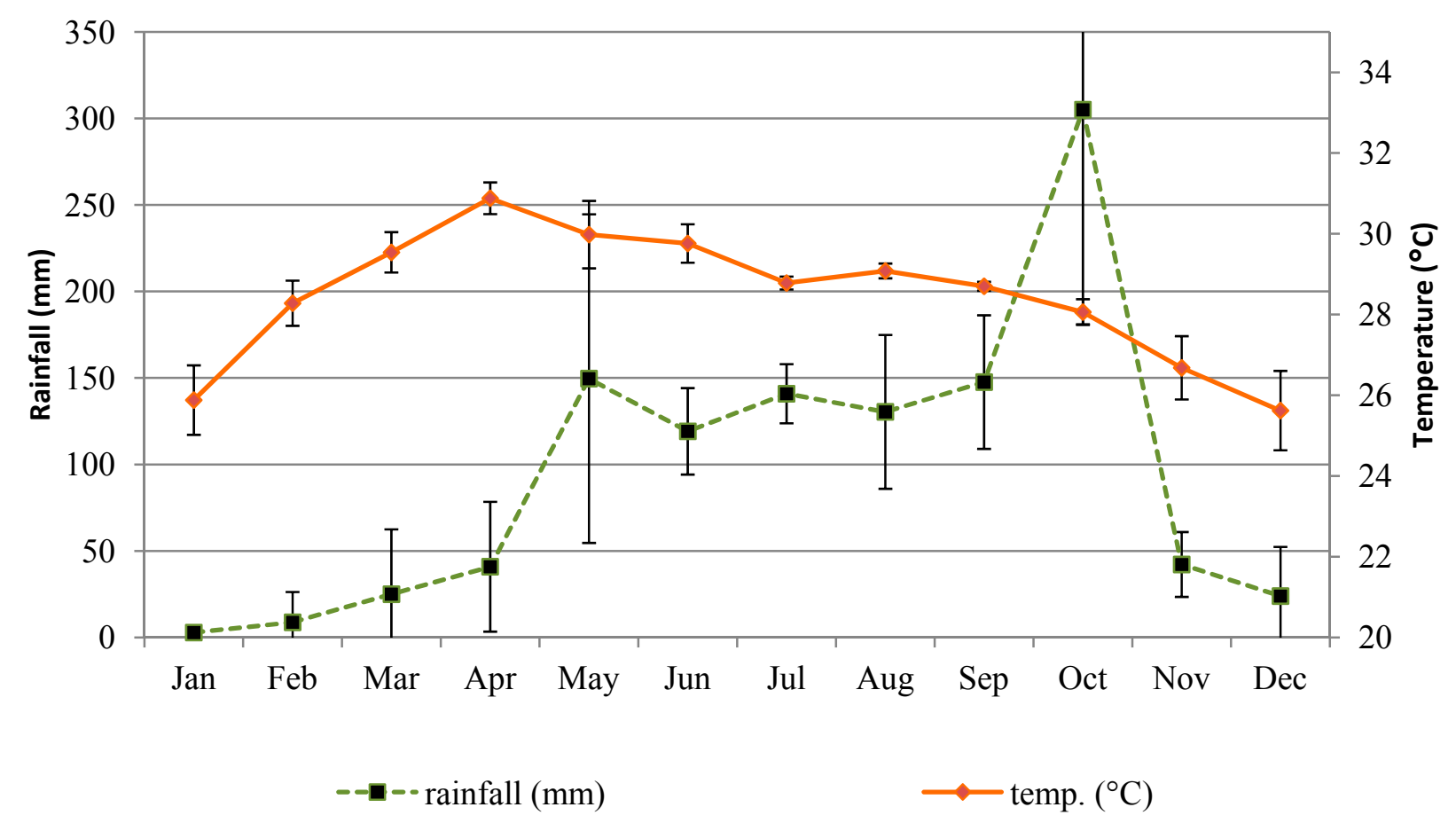

\subsection{Surface Biomass Sampling}

The surface biomass in this study was composed of leaf litter, twig, seedling, and understory (i.e., grass, climber and herb). The systematic random sampling method was used to sample surface biomass from field experiment. Four samples of surface biomass were collected from four sub-plot of 1-m $\times 1-\mathrm{m}$, as shown in Figure 3. For each one square meter sub-plot, the surface coverage of surface biomass was observed and estimated in percentage of coverage, the surface biomass bed height was measured, and the biomass fuel was cut and sampled (Figure 4). For each sampling plot, surface biomass samples were separated into fuel type including leaf litter, twig, seedling, and understory. Each category was weighed in the field to determine the wet weight. All samples were then carried to laboratory to be oven-dried at $80{ }^{\circ} \mathrm{C}$ for 24 hours or until constant weight. All samples were then weighed to determine the dry weight and moisture content.

\subsection{Fire Experiment Set $U p$}

In order to measure the fire characteristics (including fire spread rate and flame height), which led to emissions of compounds of interest, wood sticks of 1.5 meters tall with 1 meter height scale mark were placed every 5 meters on the left, central, and right lines of the plot as shown in Figure 3. The rate of fire spread was calculated using the measurement of the time taken by the flame to move between two sticks in each line. The flame height at each wood stick was recorded manually using a meter tape. 
Figure 3. Fire experiment set-up.

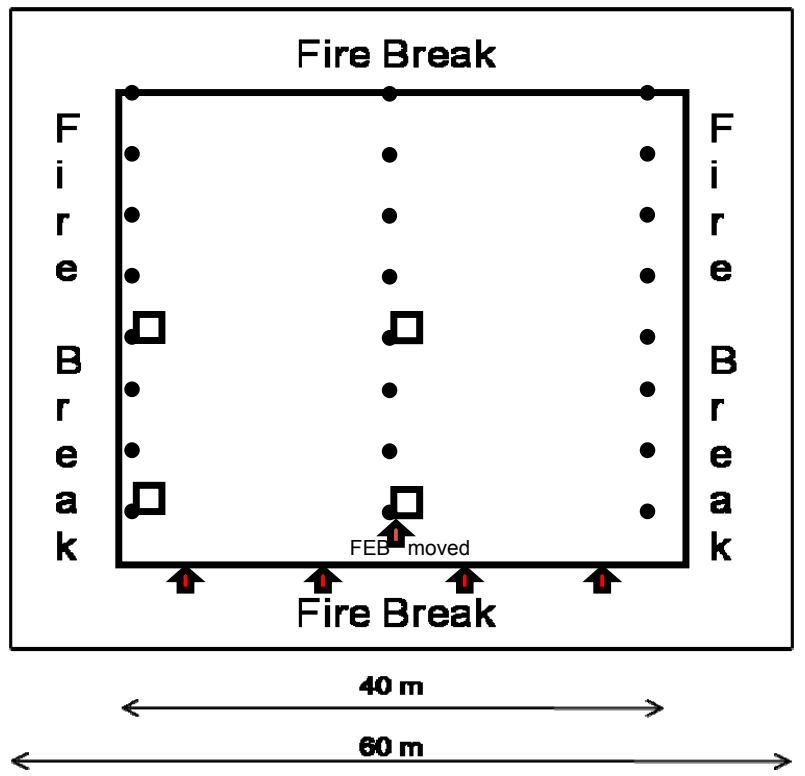

Legends: $\square$ 1-m $\times 1-\mathrm{m}$ plot for pre-burnt fuel loads, $\bullet$ wooden stick for determining the rate of fire spread and flame height, 1 burning direction and FEB (Field Equipment Box) to move on the central line.

Figure 4. Surface biomass (a) and residues after burning (b) in a 1-m $\times 1-\mathrm{m}$ sub-plot sampling.

(a)

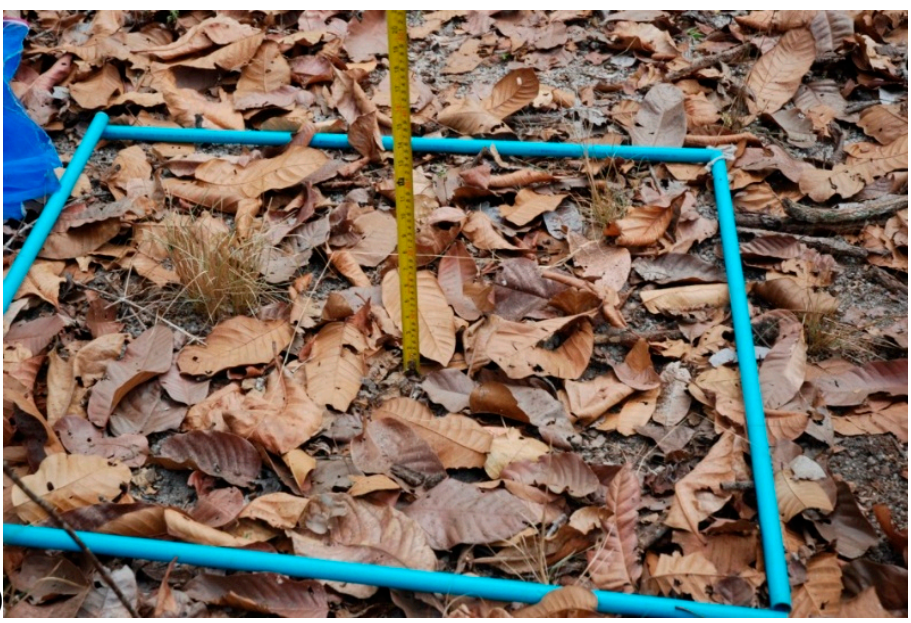

(b)

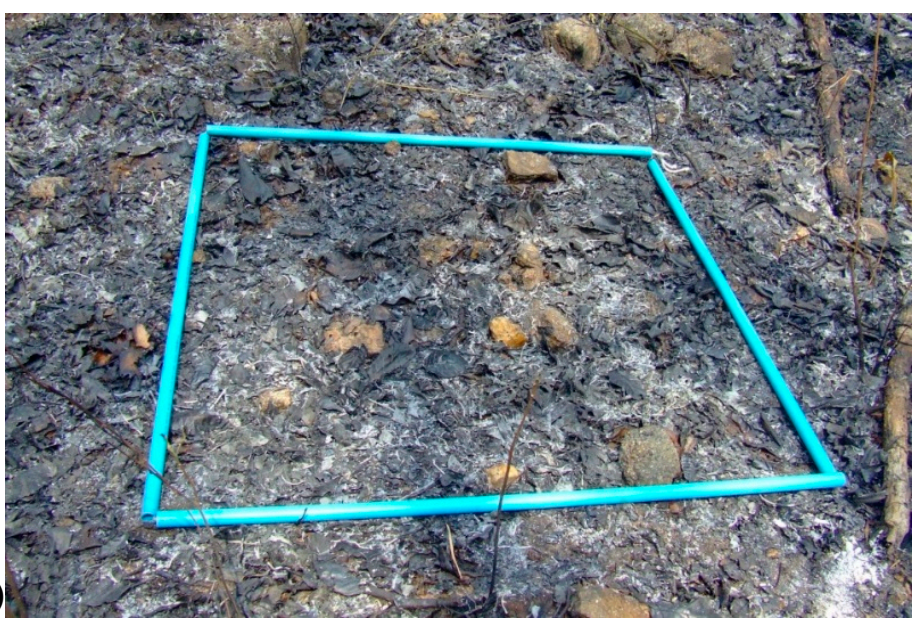


The fire was set by igniting in-line the located upwind side of the main plot. The in-line ignition was used to minimize the edge effect that may affect the fire propagation. The measurements were recorded from the three rows of wood sticks, i.e., left, central and right lines of the main plot, and not from the left and right line only to avoid perturbation of the measurement that may result from the edge effect.

\subsection{After-Fire Residues Sampling}

The residues after burning composed of ash and charred leaves were collected after the fire experiment from four sub-plots of $1-\mathrm{m} \times 1-\mathrm{m}$ using simple random method (Figure 4). The same sample handling and treatment as for surface biomass were applied to the residue samples for dry matter, and moisture and carbon content determination.

\subsection{Analysis of Carbon Content in Biomass and Residues after Burning}

After oven-dried at $80{ }^{\circ} \mathrm{C}$ for at least 24 hours or until reaching a constant weight, the leaf litter samples were cut using the cutting mill (SM 2000 model, Retsch, Germany) and ground with the ball mill ( $\mathrm{PM}_{10}$ model, Retsch, Germany) until obtaining a powder with diameter lesser than $100 \mu \mathrm{m}$. The ground samples were then analyzed for the carbon content by Organic Elemental Analyzer (Flash EA1112 NC-Soil model, ThermoFinnigan, Italy). The same analytical procedure was applied to residues after burning composed of a mixture of ash and charred leaves.

\subsection{Real-Time Measurement and Sampling of Emissions}

The background concentration measurement was conducted by real-time measurement set-up at the center of the plot for $30 \mathrm{~min}$ before ignition started. The fire was ignited at noon and the emission measurement in the plume was performed until no visible smoke was observed. The weather conditions including relative humidity, temperature, wind speed and wind directions were monitored during the whole duration of the background and fire emission measurement using a portable weather station (La Cross Technology, France). The weather station was set at about 10 meters downwind from the prescribed plot.

\subsubsection{Measurement of $\mathrm{CO}_{2}$ and $\mathrm{CO}$}

Carbon dioxide $\left(\mathrm{CO}_{2}\right)$ was analyzed using a non-dipersive infared (NDIR) detector. Carbon monoxide ( $\mathrm{CO}$ ) analysis was performed using chemical cell detection technique with a full scale resolution of $1000 \mathrm{ppm}$, repeatability of $3 \% \pm 2$ LSD (Least significant digits), and display resolution of 1 ppm. For $\mathrm{CO}_{2}$, a full scale resolution of $20,000 \mathrm{ppm}$ with display resolution of $\pm 300 \mathrm{ppm}$ was selected. The outflow connecting tubing was connected with the micro-aethalometer at a flow rate of $50 \mathrm{~mL} \cdot \mathrm{min}^{-1}$.

\subsubsection{Measurement of $\mathrm{PM}_{2.5}$}

DustTrak aerosol monitor (TSI Inc., USA), a real-time optical scattering measurement equipment, was used to measure the concentration of $\mathrm{PM}_{2.5}$ emitted from the burning. The principle of the 
measurement consists in pumping the air or smoke through the chamber to be scattered by the infra-red diode laser beam. The aerosols flow through the inlet with selected size by pump. The light scattering laser of the photo-detector determines the mass concentration of aerosol drawn to the unit in a constant stream. The mass concentration measurement is based on a calibration using the ISO 12103-1, A1 dust (Arizona Road Dust) standard.

\subsubsection{Sampling of Total Particulate Matter}

Quartz filters of $47 \mathrm{~mm}$ diameter (Pall Life Science, USA) were preheated at $800{ }^{\circ} \mathrm{C}$ for 5 hours [6] then cooled down in desiccator for 24 hours, weighed and placed in desiccator before use to collect particulate matter of the emission plume. The quartz filter was placed in an open-faced stainless steel filter holder (Pall Life Sciences, USA) connected with an individual pump operating at a flow rate of $5 \mathrm{~L} \cdot \mathrm{min}^{-1}$.

\subsubsection{Measurement of Black Carbon}

The micro-aethalometer (Magee Scientific, AE51 model, USA) uses the optical technique principle to measure the black carbon concentration at $880 \mathrm{~nm}$ wavelength. The equipment was set up for real-time measurement of the black carbon concentration at the flow rate of $50 \mathrm{~mL} \cdot \mathrm{min}^{-1}$.

\subsection{Field Equipment Box and Tower}

The field equipments for emission concentration measurement, including real-time monitoring of carbon dioxide, carbon monoxide (Quest Technologies, IAQ model AQ500Pro, USA), black carbon (Micro-aethalometer, Magee Scientific, USA), and $\mathrm{PM}_{2.5}$ (DustTrak, 8520 model, TSI, USA), and the batch sampling of total particulate matter, were set up in the field equipment box (FEB) at the top of a tower of 3 meter-height.

\subsection{Estimation of Emission Factors of Carbonaceous Compound}

\subsubsection{Carbon Mass Balance Method}

The carbon mass balance (CMB) method [7,8] was used to calculate the carbon oxidized by the combustion of biomass fuel as follows.

$$
C_{\text {input }}=C_{\text {output }} \Leftrightarrow C_{\text {biomass }}=C_{\text {ash }}+C_{\text {released }}
$$

where: $C_{\text {biomass }}$ is the amount of carbon in the biomass consumed $\left(\mathrm{gC} \cdot \mathrm{m}^{-2}\right), C_{a s h}$ is the amount of carbon in residues after burned $\left(\mathrm{gC} \cdot \mathrm{m}^{-2}\right), C_{\text {released }}$ is the amount of carbon released to the atmosphere $\left(\mathrm{gC} \cdot \mathrm{m}^{-2}\right)$.

The carbon content of biomass fuel was used to estimate the amount of carbon in the ash and released to the atmosphere. The $\mathrm{CMB}$ method $[7,8]$ was used to calculate the carbon oxidized related to the carbon in biomass before and after burning. The general equation to calculate the $\mathrm{CMB}$ in biomass combustion is illustrated in Equation (1).

In case of a complete combustion, the carbon released to the atmosphere would be equal to the carbon in the form of carbon dioxide $\left(\mathrm{CO}_{2}\right)$. As forest fire is always an incomplete combustion, the 
carbon released is composed of carbon dioxide $\left(\mathrm{CO}_{2}\right)$ representing more than $90 \%$ of the total, carbon monoxide (CO) corresponding to minor component (i.e., lesser than $5 \%$ of the total) $[5,6]$ and trace carbonaceous compounds including gaseous species such as methane $\left(\mathrm{CH}_{4}\right)$, non-methane volatile organic compounds (NMVOCs), etc., and carbon-contained particulate matter, composed of black carbon (BC) and organic carbon (OC). In this study, the carbon released to the atmosphere was estimated from the carbon in residues after burned, which was then subtracted from carbon in biomass fuel consumed.

\subsubsection{Carbon Emitted in the Form of $\mathrm{CO}_{2}$ and $\mathrm{CO}$, and Modified Combustion Efficiency (MCE)}

The CMB method was used to estimate the emission factor of $\mathrm{CO}_{2}$ because carbon dioxide is the main form of carbon released to the atmosphere with a share higher than $90 \%$ of the total carbon released [9,10]. Emission information is obtained from carbon dioxide $\left(\mathrm{CO}_{2}\right)$ and carbon monoxide (CO) emission ratio and emission factor, which relate the emission of a compound of interest and the total emission to the amount of fuel burned, respectively. The carbon mass in the form of $\mathrm{CO}_{2}$ and $\mathrm{CO}$ were calculated by Equation (2) adapted from the equation developed by Neto et al. [11].

$$
M C_{i}\left(\mathrm{gC} \cdot \mathrm{m}^{-3}\right)=\frac{[i] \times 10^{6} \times M_{i} \times 10^{3} \times C}{V_{i} \times 10^{-3} \mathrm{~m}^{3} \times M W_{i}}
$$

where: $i$ is the concentration of gas $i$ (ppmv), $M_{i}$ is the mass of carbon emitted in the form of gas $i$ in the smoke plume $(\mathrm{g}), V_{i}$ is the volume of gas $i\left(24.45 \mathrm{~L}\right.$ for 1 mole of gas at $25^{\circ} \mathrm{C}$ and $\left.1 \mathrm{~atm}\right), M W_{i}$ is the molecular mass of compound of gas $i\left(\mathrm{~g} \cdot \mathrm{mole}^{-1}\right), C$ is the molar mass of carbon $\left(\mathrm{g} \cdot \mathrm{mole}^{-1}\right)$.

The emission factor of $\mathrm{CO}_{2}$ or $\mathrm{CO}$ can be estimated using Equation (3) adapted from Urbanski et al. [12] and Neto et al. [11].

$$
E F_{i}\left(\mathrm{~g} \cdot \mathrm{kg}^{-1}\right)=\frac{M C_{i} \times 1000 \times M W_{i}}{C \times C_{t}} \times C_{m}
$$

where: $C_{m}$ is the mass fraction of carbon released to dry biomass consumed, $1000\left(\mathrm{~g} \cdot \mathrm{kg}^{-1}\right)$ and $C_{t}$ is the total mass of carbon released in the form of $\mathrm{CO}_{2}, \mathrm{CO}\left(\mathrm{mgC} \cdot \mathrm{m}^{-3}\right)$.

The modified combustion efficiency (MCE) is defined as the ratio of $\mathrm{CO}_{2}$ released to the total release of $\mathrm{CO}$ and $\mathrm{CO}_{2}$ [13]. In the open burning process, the MCE never reaches $100 \%$. The MCE can be used to describe the relative contribution of flaming and smoldering phase of biomass burning.

$$
\mathrm{MCE}=\frac{\Delta \mathrm{CO}_{2}}{\Delta \mathrm{CO}_{2}+\Delta \mathrm{CO}}
$$

\subsubsection{Estimation of Emission Factor of Emitted Carbonaceous Aerosols}

Black carbon (BC) and organic carbon (OC) are the solid carbon contained found generally in the fine fraction of atmospheric particles (i.e., $\mathrm{PM}_{2.5}$ ) The $\mathrm{OC}$ and total carbon (TC) content of atmospheric particulate matter can be estimated by Equations (5) and (6). From Ward et al. [14] and Neto et al. [11], it was found that the mass of TC represents about $60 \%$ of the total mass of $\mathrm{PM}_{2.5}$ emitted from biomass burning. The emission factor of particle species can be calculated as Equation (7). 


$$
\begin{gathered}
\mathrm{OC}=\mathrm{TC}-\mathrm{BC} \\
\mathrm{TC}\left(\mathrm{mgC} \cdot \mathrm{m}^{-3}\right)=60 \% \times \mathrm{PM}_{2.5} \\
\mathrm{EF}_{A i}\left(\mathrm{~g} \cdot \mathrm{kg}^{-1}\right)=\frac{M_{A i} \times 1000}{C_{t}} \times C_{m}
\end{gathered}
$$

where: $M_{A i}$ is the emission concentrations of carbonaceous aerosols or particulate matter of species $i\left(\mathrm{mgC} \cdot \mathrm{m}^{-3}\right), C_{m}$ is the mass fraction of carbon released to dry biomass consumed, $1000\left(\mathrm{~g}^{\circ} \mathrm{kg}^{-1}\right)$, $C_{t}$ is the total mass of carbon released in form of $\mathrm{CO}_{2}, \mathrm{CO}$ and $\mathrm{PM}_{2.5}\left(\mathrm{mgC} \cdot \mathrm{m}^{-3}\right)$.

\subsection{Morphology of Carbonaceous Aerosols Using Scanning Electron Microscope}

Particulates collected on quartz filter were conditioned in desiccator for 24 hours before analysis of the morphology by scanning electron microscopy with energy-dispersive X-ray spectroscopy (SEM-EDX) (JEOL, Model: ISM-S410LV, Japan). Each sampled filter was punched to obtain $10 \mathrm{~mm}$ diameter samples which were then gold coated before the SEM-EDX analysis. Micrographs were taken at $20 \mathrm{Kv}$ for identification and characterization of aerosols.

\section{Results and Discussion}

\subsection{Surface Biomass Fuel and After-Fire Residues Characteristics}

The depth of surface biomass varied among sites, depending on the vegetation structure and the repartitioning between living and dead fraction. The dead leaves and twig depths were about 5-10 cm and 2-6 cm, respectively. Overall 90\% coverage of surface fuel was dead leaves, followed by twig. The dead leaves load in DDF1, DDF2 and DDF3 were 561, 212 and $253 \mathrm{~g} \cdot \mathrm{m}^{-2}$, respectively. The moisture content of dead leaves was 4.69, 6.55 and 7.11\% in DDF plot number 1 to 3 , respectively. The average of dead leaves load in four plots was $342 \pm 190 \mathrm{~g} \cdot \mathrm{m}^{-2}$ and the twig load was lesser than $100 \mathrm{~g} \cdot \mathrm{m}^{-2}$. It was confirmed that the dead leaves constituted the main component of the surface biomass.

After burning, the amount of surface biomass consumed was $271 \pm 138 \mathrm{~g} \cdot \mathrm{m}^{-2}$. It was observed that twig kept the same shape as before burning. Therefore, dead leaves were the major fuel consumed. The residues after burning or fire included the charred leaves and ash. The mass of residues after burning was $39 \pm 13 \mathrm{~g} \cdot \mathrm{m}^{-2}$. It should be noted that it was difficult to separate charred leaves from ash for quantification of the mass load.

\subsection{Carbon Content in Surface Biomass and After-Fire Residues}

The carbon content of dead leaves and small twig before burning was $45.81 \pm 0.04 \%$ and $43.49 \pm 0.09 \%$, respectively. The carbon content in the residues was $35.0 \pm 0.06 \%$. The carbon content in the dead leaves and residues after burning are reported in Table 1.

From Table 1, it was found that the carbon released to the atmosphere from the DDF fires represented $88.38 \pm 2.02 \%$ of the initial dead leaves carbon content. The results showed that each gram of carbon released to the atmosphere corresponded to $2.40 \pm 0.02 \mathrm{~g}$ of dead leaves consumed by fires in DDF. 
Table 1. Carbon content in the dead leaves consumed, after-fire residues and released to the atmosphere.

\begin{tabular}{ccc}
\hline & Carbon $\mathbf{( g C \cdot \mathbf { m } ^ { - \mathbf { 2 } } )}$ \\
\hline Dead leaves consumed & After-fire Residues & Released to atmosphere \\
$124.83 \pm 63.36$ & $13.75 \pm 4.57$ & $111.07 \pm 58.88$ \\
\hline
\end{tabular}

Carbon in after-fire residues would be left on the ground surface and returned to forest soil to enhance its carbon stock in the long term. The percentage of carbon in the residues was $11.25 \pm 2.11 \%$ of the total carbon in the surface biomass fuel consumed. It was shown that the amount of carbon returned to the ecosystem in the form of a mixture of ash and charred leaves in this forest type is $53.85 \pm 9.67 \mathrm{gC} \cdot \mathrm{kg}^{-1}$ dry biomass.

\subsection{Carbon Released to the Atmosphere}

In this study, the carbon released to the atmosphere resulted from dead leaves burning was $88.38 \pm 2.02 \%$ the initial dead leaves fuel carbon content. This indicates that each gram of carbon released was resulted from about $2.40 \pm 0.02 \mathrm{~g}$ of dry dead leaves, which is in good agreement with the result obtained by Nelson from laboratory fire experiments [13]. It is also of the same order of magnitude as the laboratory experimental result found by Chaiyo et al. [15] which stated that each gram of carbon released was produced from the combustion of DDF dead leaves was $2.27 \pm 0.01 \mathrm{~g}$.

The assessment of the amount of carbon released to the atmosphere from fires in Mae Nam Phachi wildlife sanctuary during 2007 to 2010 indicated that the average of carbon to the atmosphere was $6.04 \pm 3.88$ tonnes $\mathrm{C} \cdot \mathrm{y}^{-1}$.

\subsection{Modified Combustion Efficiency (MCE) and Emission of Carbonaceous Compound}

The amount of biomass burned in DDF1 was $430.41 \mathrm{~g}$. Overall, the combustion in DDF plot was flaming dominant, indicating that the combustion completeness should be higher than 0.90 [16], and MCE should range between $0.70-0.99$. The MCE found in this study was $0.93 \pm 0.05$.

\subsection{Estimated Emission Factors of $\mathrm{CO}_{2}, \mathrm{CO}$ and Carbonaceous Related Compounds}

The total amount of carbon emitted from DDF was calculated from the biomass consumed for each gram of carbon emitted. The fraction of $\mathrm{PM}_{2.5}$ which includes $\mathrm{BC}$ and $\mathrm{OC}$ was estimated from the total carbon associated to $\mathrm{PM}_{2.5}$. The total carbon (TC) was assumed to represent $60 \%$ of the total mass of $\mathrm{PM}_{2.5}$ based on Ward et al. [17]. The percentage of carbon associated to $\mathrm{CO}_{2}$ never exceeded $90 \%$ of the total mass of carbon released (Table 2).

Table 2. Mass of carbon associated with measured pollutants, mass of biomass consumed, and $\%$ carbon associated to $\mathrm{CO}_{2}$ released from leaf litter burning.

\begin{tabular}{|c|c|c|c|c|c|c|c|c|}
\hline \multirow[b]{2}{*}{ Plot } & \multicolumn{6}{|c|}{ Carbon $\left(\mathrm{mg} \cdot \mathrm{m}^{-3}\right)$} & \multirow{2}{*}{$\begin{array}{c}\text { Mass of Biomass } \\
\text { Consumed } \\
\left(\mathrm{g} \cdot \mathrm{gC}^{-1}\right) \\
\end{array}$} & \multirow[b]{2}{*}{$\% \mathrm{C}_{\mathrm{CO}_{2}}$} \\
\hline & $\mathbf{m}_{\mathrm{C}-\mathrm{CO}_{2}}$ & $\mathbf{m}_{\mathrm{C}-\mathrm{CO}}$ & $\mathbf{m}_{\mathrm{C}-\mathrm{BC}}$ & $\mathbf{m}_{\mathbf{C}-\mathbf{P M}} \mathbf{H}_{2.5}$ & $\mathbf{m}_{\mathrm{C}-\mathrm{OC}}$ & $\mathbf{m}_{\mathrm{C} \text {-total }}$ & & \\
\hline DDF1 & 196.75 & 20.92 & 0.42 & 8.53 & 8.11 & 226.20 & 2.40 & 86.98 \\
\hline
\end{tabular}


The emission factors reported in Table 3 for $\mathrm{CO}_{2}, \mathrm{CO}, \mathrm{PM}_{2.5}$ and $\mathrm{BC}$ were calculated from the real-time measurement data from field experiment. Emission concentrations of $\mathrm{OC}$ was deduced from total organic carbon (TC) associated in $\mathrm{PM}_{2.5}$. In the fire experimental plot, the emission factors of $\mathrm{BC}$ and $\mathrm{OC}$ were 0.77 and $14.94 \mathrm{~g} \cdot \mathrm{kg}^{-1}$ dry biomass burned, respectively.

Table 3. Emission factors of measured compound emitted from dry dipterocarp forest determined using.

\begin{tabular}{cccccc}
\hline \multirow{2}{*}{ Plot } & \multicolumn{5}{c}{ Emission Factor $\left(\mathbf{g}^{\cdot \mathbf{k g}} \mathbf{}^{-1}\right.$ dry biomass burned $)$} \\
\cline { 2 - 6 } & $\mathbf{E F}_{\mathbf{C O}} \mathbf{2}$ & $\mathbf{E F}_{\mathbf{C O}}$ & $\mathbf{E F}_{\mathbf{B C}}$ & $\mathbf{E F}_{\mathbf{P M}_{25}}$ & $\mathbf{E F}_{\mathbf{O C}}$ \\
\hline \multirow{2}{*}{ DDF1 } & 1329 & 90 & 0.77 & 26.19 & 14.94 \\
\hline
\end{tabular}

The comparison of emission factors from this study with other research works is displayed in Table 4 . It was shown that the overall emission of $\mathrm{CO}_{2}$ from others was higher compared to this study. However, the ratios of $\mathrm{CO}$ and $\mathrm{CO}_{2}$ are of the same range. The $\mathrm{BC}$ emission factor from this study was found higher than from the same forest zone such as tropical and extra-tropical forest fires, while the ratio of $\mathrm{CO}$ and $\mathrm{CO}_{2}$ was similar, indicating a quite equivalent fire behavior.

Table 4. Comparison of emission factors determined in this study with other research works on emissions from tropical forest fires.

\begin{tabular}{|c|c|c|c|c|c|c|c|}
\hline \multirow{2}{*}{ Forest Type } & \multicolumn{6}{|c|}{$\mathrm{EF}\left(\mathrm{g} \cdot \mathrm{kg}^{-1}\right.$ dry biomass burned $)$} & \multirow{2}{*}{ Ref. } \\
\hline & $\mathrm{CO}_{2}$ & $\mathrm{CO}$ & BC & $\mathbf{P M}_{2.5}$ & TPM & OC & \\
\hline Dry dipterocarp forest & 1329 & 90 & 0.77 & 26.19 & - & 14.94 & This study \\
\hline Savanna and grassland & $1613 \pm 95$ & $65 \pm 20$ & $0.48 \pm 0.18$ & $5.4 \pm 1.5$ & $8.3 \pm 3.2$ & $3.4 \pm 1.4$ & {$[10]$} \\
\hline Tropical forest & $1580 \pm 90$ & $104 \pm 20$ & $0.66 \pm 0.31$ & $9.1 \pm 1.5$ & $6.5-10.5$ & $5.2 \pm 1.5$ & [10] \\
\hline Extra tropical forest & $1569 \pm 131$ & $107 \pm 37$ & $0.56 \pm 0.19$ & $13 \pm 7.0$ & $17.6 \pm 6.4$ & $8.6-9.7$ & [10] \\
\hline Amazonian forest & & & & & - & & [11] \\
\hline Canisters & 1599 & 111.3 & & 4.84 & - & - & \\
\hline RT FASS * & 1617 & 137.6 & & & & - & \\
\hline Primary tropical forest & 1601 & 107.8 & & 14.8 & & & [18] \\
\hline Pasture maintenance fire & 1506 & 152.4 & & 18.7 & & & [18] \\
\hline Tropical forest & 1643 & 93 & 0.52 & 9.1 & & 4.71 & [19] \\
\hline Extra tropical forest & 1509 & 122 & 0.56 & 15.0 & & & [19] \\
\hline
\end{tabular}

Notes: ${ }^{R}$ RT-FASS means Real-Time Fire-Atmosphere Sampling System.

Table 5 reported the emission fluxes of $\mathrm{BC}$ and $\mathrm{OC}$ estimated for DDF fires in Thailand as documented in other studies using the emission factors of BC and $\mathrm{OC}$ determined in this study. The estimation may be affected by some uncertainty because the amount of residues after burning and their carbon content were not available, and so the combustion completeness. The $\mathrm{BC}$ and $\mathrm{OC}$ emission fluxes, expressed in $\mathrm{g} \cdot \mathrm{m}^{-2}$, found for DDF located in Kanchanaburi, HKK and Phu Kradueng are similar to that in MNP, i.e., our study site.

The emission factors of $\mathrm{BC}$ and $\mathrm{OC}$ obtained in this study were used to estimate the emissions of BC and OC from DDF fires in Thailand during 2002 to 2006. It was found that the emission of BC and OC from DDF amounted 17.43 and 336.83 tonnes $\cdot \mathrm{y}^{-1}$, respectively. 
Table 5. Comparison of emission fluxes of BC and OC from dry dipterocarp forest fires in this site with the other research studies.

\begin{tabular}{|c|c|c|c|c|c|}
\hline \multirow{2}{*}{ Location Study } & \multirow{2}{*}{$\begin{array}{c}\text { Fuel Load } \\
\left(\mathrm{g} \cdot \mathrm{m}^{-2}\right)\end{array}$} & \multirow{2}{*}{$\begin{array}{c}\begin{array}{c}\text { Fuel Consumed } \\
\left(\mathrm{g} \cdot \mathrm{m}^{-2}\right)\end{array} \\
\end{array}$} & \multicolumn{2}{|c|}{ Emission Fluxes $\left(\mathrm{g} \cdot \mathrm{m}^{-2}\right)$} & \multirow{2}{*}{ Reference } \\
\hline & & & BC & OC & \\
\hline Kanchanaburi & 440 & 300 & 0.23 & 4.48 & [20] \\
\hline HKK * & 500 & 450 & 0.35 & 6.72 & [21] \\
\hline HKK & 810 & 320 & 0.25 & 4.78 & [21] \\
\hline HKK & 110 & 530 & 0.41 & 7.92 & [22] \\
\hline Phu Kradueng & 470 & 290 & 0.22 & 4.33 & [23] \\
\hline MNP ** & 342 & 271 & 0.21 & 4.05 & This study \\
\hline
\end{tabular}

Notes: * HKK means Huay Kha Khaeng Wildlife Sanctuary, Uthai Thani Province; ** MNP means Mae Nam Phachi Wildlife Sanctuary, Ratchaburi Province.

\subsection{Morphology of Carbonaceous Aerosols}

The SEM micrographs of TPM showed various morphological types (Figure 5). The micrographs from the burning of DDF indicated 8 shapes of carbonaceous aerosols. The elemental composition analysis of each micrograph found the presence of carbon $(\mathrm{C})$, oxygen $(\mathrm{O})$, aluminum $(\mathrm{Al})$, chlorine $(\mathrm{Cl})$, potassium $(\mathrm{K})$, iron $(\mathrm{Fe})$ and calcium $(\mathrm{Ca})$. DA micrograph shows the dominant shape, followed by DB, DH and DG micrographs, respectively. The DB and DH micrographs display similar shapes of branched clusters of soot particles as obtained by Pachauri et al. [24].

\subsection{Contribution to Global Warming of Emissions from DDF Fires}

Table 6 presents the emissions from annual DDF fires in Thailand in $\mathrm{CO}_{2}$ equivalent, using the Global Warming Potential (GWP) of $\mathrm{CO}_{2}, \mathrm{CO}, \mathrm{BC}$ and $\mathrm{OC}$, the main carbon components measured in this study.

Figure 5. SEM micrographs of particulate matter emitted from dry dipterocarp forest fires in Thailand.
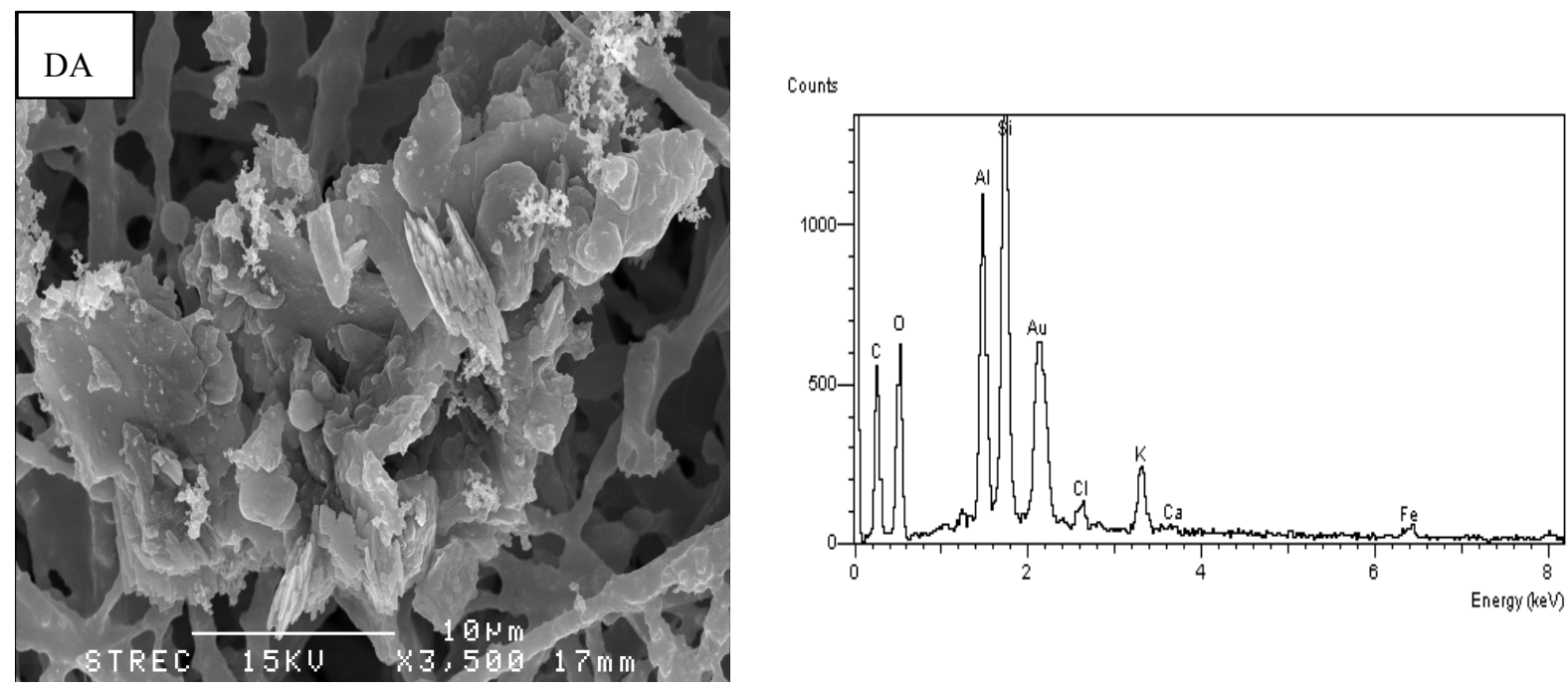
Figure 5. Cont.
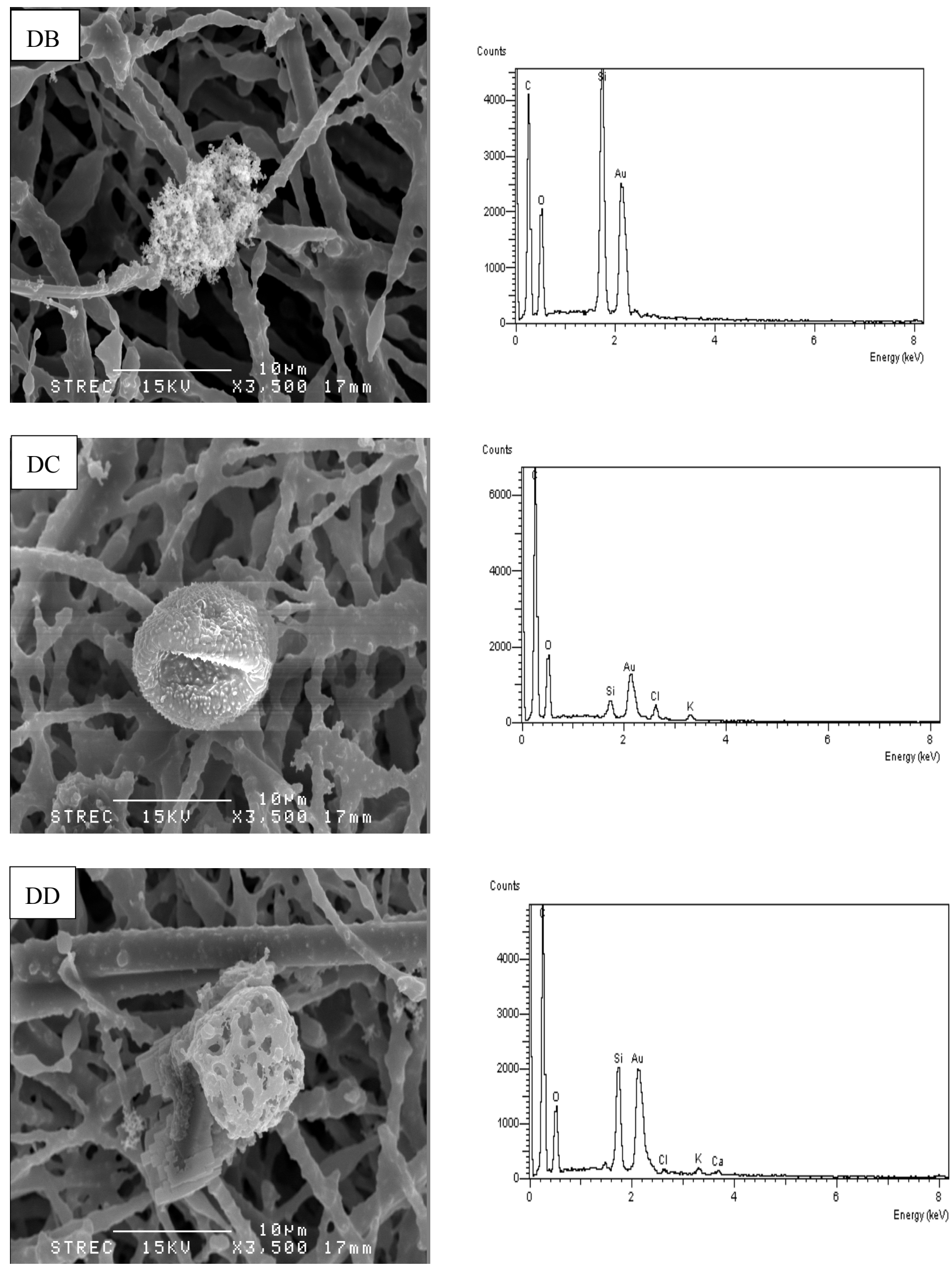
Figure 5. Cont.
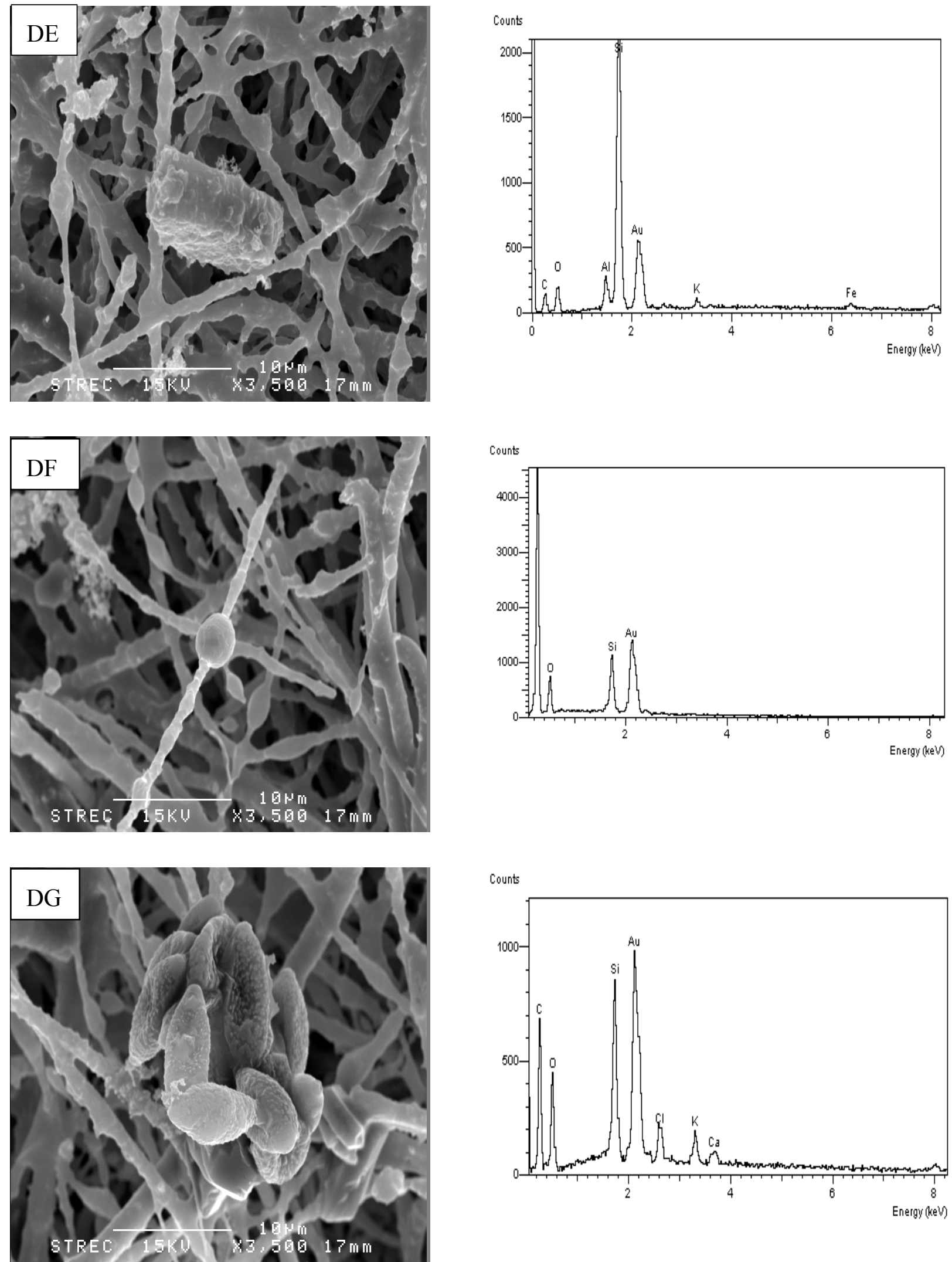
Figure 5. Cont.
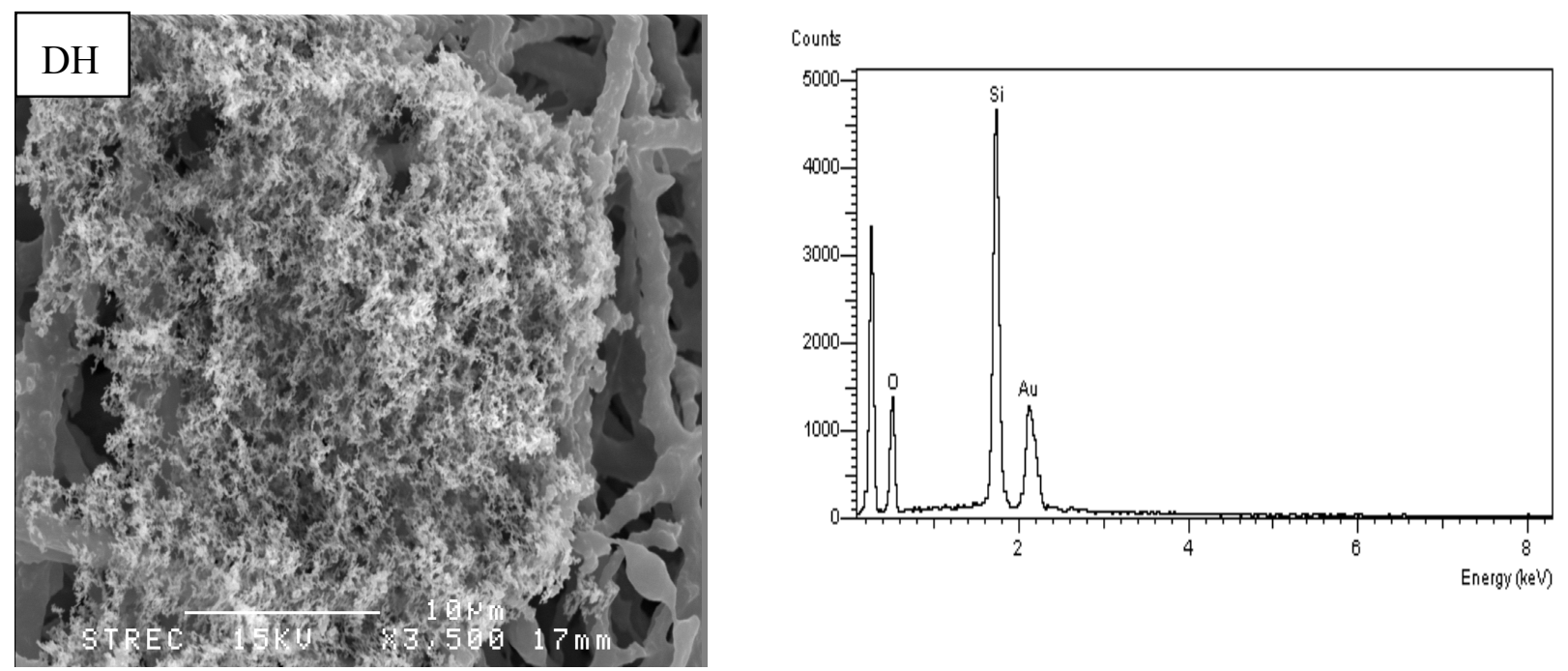

Table 6. Contribution to global warming of emissions from dry dipterocarp forest fires in Thailand.

\begin{tabular}{|c|c|c|c|c|c|}
\hline \multirow{2}{*}{ Species } & \multicolumn{2}{|c|}{ GWP } & \multirow{2}{*}{$\begin{array}{c}\text { Emissions } \\
\left.\left(\text { tonnes }^{-1}\right)^{-1}\right)\end{array}$} & \multicolumn{2}{|c|}{ Tonnes $\left.\cdot \mathrm{CO}_{2 \mathrm{eq}} \cdot \mathrm{y}^{-1}\right)$} \\
\hline & $20 \mathrm{y} *$ & $100 \mathrm{y}^{*}$ & & $20 \mathrm{y}$ & $100 \mathrm{y}$ \\
\hline $\mathrm{CO}_{2}$ & 1 & 1 & 29,964 & $+29,964$ & $+29,964$ \\
\hline $\mathrm{CO}$ & 6 & 2 & 2027 & $+12,165$ & +4055 \\
\hline $\mathrm{BC}$ & 1600 & 460 & 17 & $+27,886$ & +8017 \\
\hline $\mathrm{OC}$ & -240 & -69 & 337 & $-80,840$ & $-23,242$ \\
\hline
\end{tabular}

Notes: * [25], $(+)$ means warming and $(-)$ means cooling.

The GWP metric is used to determine the relative radiation effect of a given emission mass of a species compared to $\mathrm{CO}_{2}$ integrated over a chosen time horizon. Generally, 20 year and 100 year time horizons are used to calculate the GWP of a given compound. In addition, BC and OC are usually estimated based on 20 year time horizon, because of their shorter lifetime compared to traditional greenhouse gas. It was found that on the basis of 20 year time horizon in tonnes $\cdot \mathrm{CO}_{2 \text { eq }}$ per year unit, the emission of $\mathrm{BC}$ by dry dipterocarp forest fires can induce similar warming effect as the co-emitted $\mathrm{CO}_{2}: 27,886$ tonnes $\cdot \mathrm{CO}_{2 \mathrm{eq}} \cdot \mathrm{y}^{-1}$ vs. 29,964 tonnes $\cdot \mathrm{CO}_{2 \mathrm{eq}} \cdot \mathrm{y}^{-1}$ (Table 6).

\section{Conclusions}

The surface biomass is composed of leaf litter and small twig. Dead leaves represent more than $90 \%$ of the total surface biomass whether weight or ground surface coverage basis, and hence constitute the main fuel for combustion. Another fraction that may influence the biomass combustion process investigated in this study are small twigs, but at a level much smaller than dead leaves. Based on the field experiment measurement data, it was estimated that the amount of carbon released by DDF fires in Thailand during 2002 to 2006 was 9241.46 tonnes $\cdot y^{-1}$, and about 3.37 tonnes $\cdot y^{-1}$ of carbon was returned to soil. Also, it was shown that Chiangmai represents the province where more than $50 \%$ of 
the total carbon released from DDF fires in 2009 followed by Lampoon, Khon Kaen, and Karlasin, respectively.

The morphology of carbon contained particulate matter emitted from DDF fires investigated in the study included 8 shapes. Moreover, it was observed that the color of the particles collected from DDF fires were grey to black, indicating high presence of BC. It was found that $\mathrm{BC}$ represented about $8.25 \%$ of the total mass of $\mathrm{PM}_{2.5}$ emitted from DDF fires. Using the emission fluxes of $\mathrm{BC}$ and carbon released obtained in this study, it was found that $\mathrm{BC}$ constitutes about $1.89 \times 10^{-3}\left({ }^{\sim} 0.19 \%\right)$ of the carbon released to the atmosphere from DDF fires.

Using the 20 year and 100 year time horizon GWP of BC, this study showed that for 20 year time horizon, $\mathrm{BC}$ emitted from DDF in Thailand may induce the same global warming effect as co-emitted $\mathrm{CO}_{2}$.

\section{Acknowledgments}

This research was financially supported by the Joint Graduate School of Energy and Environment (JGSEE)-Center for Energy Technology and Environment (CEE-PERDO), King Mongkut's University of Technology Thonburi, through PhD scholarship program. The authors also gratefully acknowledged the financial support from the Commission on Higher Education, Ministry of Education, under the National Research University (NRU) grant. We gratefully thank Utit Phookate and the staff of Ratchaburi Forest Fire Control station. We would like to convey our sincerest thanks to Dachochai Wilairat and Sudhathai Wilairat for their field work assistance. We would like to extend our appreciation to the Aerosol from Biomass Burning to the Atmosphere (ABBA) research group, Joint Graduate School of Energy and Environment (JGSEE), King Mongkut's University of Technology Thonburi (KMUTT), for the technical support throughout the study.

\section{Author Contributions}

Both authors contributed to the research and field experiment design of this study, and to the elaboration of this manuscript. Ubonwan Chaiyo performed the data collection and analysis, and prepared the first draft of this paper. Savitri Garivait supervised the overall research work, provided guidelines for the write up of the manuscript, and contributed to its editing and finalization.

\section{Conflicts of Interest}

The authors declare no conflict of interest.

\section{References}

1. Forest Fire Control Yearly Report; National Park Wildlife and Plant Conservation Department, Forest Fire Control Office: Bangkok, Thailand, 2005.

2. Samran, S. Effect of forest fire on change in above ground biomass in the Maeklong mixed deciduous forest, Kanchanaburi province, Thailand. In Proceedings of the Conference on Climate Change in Forest: The Potential of Forest in Support of the Kyoto Protocol, Bangkok, Thailand, 4-5 August 2005. 
3. Suthivanit, S. Effects of Fire Frequency on Vegetation in Dry Dipterocarp Forest at Sakarat, Changwat Nakorn Ratchasima. Master's Thesis, Kasetsart University, Bangkok, Thailand, 1998.

4. Wanthongchai, K.; Bauhus, J.; Goldammer, J.G. Nutrient losses through prescribed burning of aboveground litter and understorey in dry dipterocarp forests of different fire history. Catena 2008, 74, 321-332.

5. Chaiyo, U.; Savitri, G.; Wanthongchai, K. Carbon storage in above-ground biomass of tropical deciduous forest in Ratchaburi Province, Thailand. World Acad. Sci., Eng. Technol. 2011, 58, 636-641.

6. Cao, G.; Zhang, X.; Gong, S.; Zheng, F. Investigation on emission factors of particulate matter and gaseous pollutants from crop residue burning. J. Environ. Sci. 2008, 20, 50-55.

7. Ward, D.E.; Nelson, R.M.; Adams, D.F. Forest fire smoke plume documentation. In Proceedings of the 72nd Annual Meeting, Air Pollution Control Association, Cincinnati, OH, USA, 21-29 June 1979.

8. Radke, L.F.; Lyons, J.H.; Hobbs, P.V.; Hegg, D.A.; Sandberg, D.V.; Ward, D.E. Airborne Monitoring and Smoke Characterization of Prescribed Fires on Forest Lands in Western Washington and Oregon; PNW-GTR-251; U.S. Department of Agriculture, Forest Service, Northwest Research Station: Portland, OR, USA, 1990.

9. Reid, J.S.; Koppman, R.; Eck, R.F.; Eluterio, D.P. A review of biomass burning emissions part II: Intensive physical properties of biomass burning particles. Atmos. Chem. Phys. 2005, 5, 799-825.

10. Andreae, M.O.; Merlet, P. Emissions of trace gases and aerosols from biomass burning. Glob. Biogeochem. Cycles 2001, 15, 955-966.

11. Neto, T.G.S.; Carvalho, J.A.; Veras, C.A.G.; Alvarado, E.C.; Gielow, R.; Lincoln, E.N.; Christian, T.J.; Yokelson, R.J.; Santos, J.C. Biomass consumption and $\mathrm{CO}_{2}, \mathrm{CO}$ and main hydrocarbon gas emissions in an Amazonian forest clearing fire. Atmos. Environ. 2009, 43, 438-446.

12. Urbanski, P.U.; Hao, W.M.; Baker, S. Chemical composition of wildland fire emissions. Dev. Environ. Sci. 2009, 8, 79-107.

13. Nelson, R.M. An Evaluation of Carbon Mass Technique for Estimating Emission Factors and Fuel Consumption in Forest Fires; U.S. Department of Agriculture, Forest Service, Southeastern Research Station: Asheville, NC, USA, 1982.

14. Ward, D.E.; Radke, L.F. Emission measurements from vegetation fires: A comparative evaluation of methods and results. Fire Environ.: Ecol. Atmos. Clim. Importance Veg. Fires 1993, 13, 53-76.

15. Chaiyo, U.; Pizzo, Y.; Garivait, S. Estimation of carbon released from dry dipterocarp forest fires in Thailand. Int. J. Environ. Sci. 2013, 7, 522-525.

16. Babitt, R.E.; Ward, D.E.; Susot, R.A.; Artaxo, P.; Kauffman, J.B. A comparison of concurrent airborne and ground-based emissions Generated from biomass burning in the Amazon Bazin. In SCAR-B (Smoke/Sulfate, Clouds and Radiation-Brazil) Proceedings, Transtec, Sao Paulo, Brazil, 1996.

17. Ward, D.E.; Hao, W.M. Air toxic emissions from burning of biomass globally-Preliminary estimate. In Proceedings of the 85th Annual Meeting, Air and Waste Management Association, Kansas City, MO, USA, 1993.

18. Yokelson, R.J. The tropical forest and fire emissions experiment: Laboratory fire measurements and synthesis of campaign data. Atmos. Chem. Phys. 2008, 8, 3509-3527. 
19. Akagi, S.K.; Yokelson, R.J.; Wiedinmyer, C.; Alvarado, M.J.; Reid, J.S.; Karl, T.; Crounse, J.D.; Wennberg, P.O. Emission factors for open and domestic biomass burning for use in atmospheric models. Atmos. Chem. Phys. 2011, 11, 4039-4072.

20. Weerapole, K. The Effect of Forest Fire for Champeria manillana (Bliume) Merr. in Kanjanaburi Province, Thailand; National Park Wildlife and Plant Conservation Department: Bangkok, Thailand, 2003.

21. Himmapan, W. Behavior, Effect and Smoke Composition of Burning Fire in Dry Dipterocarp Forest at Huay Kha Khaeng Wildlife Sanctuary, Uthai Thani Province. Ph.D. Thesis, Kasetsart University, Bangkok, Thailand, 2004.

22. Sompoh, B. Fuel Complex in Dry Dipterocarp and Mixed Deciduous Forests at Huai Kha Khaeng Wildlife Sanctuary, Changwat Uthai Thani. Master's Thesis, Kasetsart University, Bangkok, Thailand, 1998.

23. Sudthichart, K. Impact of Fire on Soil and Plant at Phu Kradung National Park. Master's Thesis, Kasetsart University, Bangkok, Thailand, 1996.

24. Pachauri, T.; Satsangi, A.; Singla, V.; Lakhani, A.; Kumari, K.M. Characteristics and sources of carbonaceous aerosols in $\mathrm{PM}_{2.5}$ during wintertime in Agra, India. Aerosol Air Qual. Res. 2013, 13, 977-991.

25. Permadi, D.A.; Kim Oanh, N.T. Assessment of biomass open burning emissions in Indonesia and potential climate forcing impact. Atmos. Environ. 2013, 27, 250-258.

(C) 2014 by the authors; licensee MDPI, Basel, Switzerland. This article is an open access article distributed under the terms and conditions of the Creative Commons Attribution license (http://creativecommons.org/licenses/by/4.0/). 